\title{
"A mala não é dela": saber das crianças em contexto escolar de fronteira
}

"The backpack is not yours:" Children and knowledge in context

"La maleta no es suya": niños y conocimiento en contexto

Artigo de investigação | Artículo de investigación

Data de recebimento: 25 de junho de 2019

Data de aceitação: 04 de fevereiro de 2020

Data de disponibilidade on-line: março de 2021

doi: 10.11144/Javeriana.m14.mned

Regina Coeli Machado e Silva coeli.machado@yahoo.com.br Universidade Federal de Integração Latino-Americana (Unila), Brasil (D) ORCID: https://orcid.org/0000-0002-0874-8086

Para citar este artículo | To cite this article Machado e Silva, R. C. (2021). "A mala não é dela": saber das crianças em contexto escolar de fronteira. magis, Revista Internacional de Investigación en Educación, 14, 1-33. doi: 10.11144/Javeriana.m14.mned 


\title{
Resumo
}

O objetivo deste artigo é apresentar um saber comum das crianças sobre um modo de vida de trabalho de adultos, visível em uma escola fundamental em Foz do Iguaçu, Brasil, na fronteira com o Paraguai. Na introdução, circunscrevo o contexto da etnografia por meio de considerações téorico-metodológicas. Apresento, primeiro, a paradoxal presentificação da fronteira do Estado-Nação brasileiro na experiência escolar; segundo, a gramática moral do trabalho ilegal visto como legítimo; e, terceiro, exponho o saber das crianças da escola a respeito desse trabalho, explicitado por elas diante das cenas de um curta metragem exibido na sala de aula.

\section{Palavras-chave}

Educação; escola; etnografia com crianças; fronteira Brasil/Paraguai

\section{Resumen}

El objetivo de este artículo es presentar un saber común de los niños y niñas sobre el modo de vida laboral de los adultos, visible en una escuela de primaria en Foz de Iguazú, Brasil, en la frontera con Paraguay. En la introducción, circunscribo el contexto de etnografía a partir de consideraciones teóricometodológicas. Primero, presento la paradójica presentación de la frontera del Estado nación brasileño en la experiencia escolar; segundo, la gramática moral del trabajo ilegal visto como legítimo, y, tercero, expongo el saber de los niños y niñas de la escuela en relación con ese trabajo, explicado por ellos, mediante las escenas de un cortometraje exhibido en la sala de clases.

\section{Palabras clave}

Educación; escuela; etnografía con niños; frontera Brazil-Paraguay

\begin{abstract}
The objective of this article is to present the common knowldge of boys and girls about the working life of adults, visible in a primary school in Foz de Iguazú, Brazil, in the border with Paraguay. In the introduction, I circumscribe the context of ethnography from theoretical-methodological considerations. First, I present the paradoxical presentation of the border of the Brazilian State-nation in the school experience, second, the moral grammar of illegal work seen as legitimate, and, third, I present the knowledge of boys and girls of the school in relation to that work, explained by them through the scenes of a short film projected in the classrooms.
\end{abstract}

\section{Keywords}

Education; school; ethnography with children; Brazil-Paraguay border 
Descripción del artículo | Article description

$\mathrm{O}$ artigo é resultado de uma pesquisa etnográfica em andamento e mais abrangente, derivada do projeto Em escola de fronteira: autoentendimentos compartilhados e segredo público, que tem como objetivo geral compreender as formas de presentificação do Estado-Nação brasileiro na fronteira do Brasil com o Paraguai e Argentina. O artigo apresenta um saber comum das crianças sobre um modo de vida de trabalho de adultos na fronteira, apreendido por meio da participação das crianças na etnografia em uma escola pública de ensino fundamental.

\section{Introdução}

O objeto temático apresentado é parte de um projeto mais abrangente ${ }^{1}$, desenvolvido em uma escola pública em Foz do Iguaçu, que visa compreender as formas paradoxais de presentificação do Estado-Nação brasileiro na fronteira, interrogando sobre modos de vida de pessoas que vivem, por meio do trabalho, a disjunção entre o ilegal e o legítimo, entre o ilícito e o rotineiro. Trata-se de pessoas que transportam mercadorias de Ciudad del Este/Paraguai, para Foz do Iguaçu/Brasil, fora dos limites legais, atividade tipificada como crime de contrabando e descaminho². A maioria delas reside no bairro onde está localizada a escola. Por essa razão a elegi como um espaço social privilegiado para observar os atos do Estado feitos - na forte presença da governabilidade dos programas educacionais nacionais, nas práticas e nos saberes escolares - e (des) feitos, nas formas de experimentação e de engajamento, advindas das injunções entre a legitimidade e a ilegalidade dessa ocupação. Ao apresentar uma diversidade de atores, a escola é inseparável das formas de saber e de modos de vida do bairro e da cidade, bem como está inserida nas tensões entre diferentes lógicas (política, jurídica e educacional) implicadas nos atos do Estado que nela convergem.

1 Intitulado Em escola de fronteira: autoentendimentos compartilhados e segredo público, tem apoio do Conselho Nacional de Desenvolvimento Científico e Tecnológico (CNPq), na modalidade Produtividade em Pesquisa.

2 Crimes contra o Estado, o contrabando e o descaminho são temas comuns em etnografias sobre fronteiras situadas em diferentes países, sobretudo a partir do século XIX (Donnan \& Wilson, 1999). Interessante lembrar que, na etimologia de contrabando, a palavra bando se refere a grupo de pessoas banidas da comunidade por ato legal de expulsão, enquanto descaminho significa sair do caminho, desvio, desrespeito pelas regras. 
Neste artigo, apresento o saber das crianças sobre o modo de vida dessa ocupação de adultos. Esse saber tornou-se visível pelo pouco interesse e pela ausência de curiosidade demonstrados por elas diante das cenas de um curta-metragem intitulado Bicitáxi exibido na escola e cujo tema central é o fluxo de coisas e pessoas pela fronteira. A recepção do curta, discutida na última parte deste artigo, é reveladora da pesquisa com participação de crianças em contextos que nos são próximos, pois aborda um tipo de travessia vivida e vista por muitos de nós moradores na fronteira entre Brasil e Paraguai. Os meninos e as meninas dessa escola residem no "Jupira", parte mais baixa da encosta às margens do rio Paraná do lado brasileiro, que delimita a fronteira, e muito próxima da ponte que une/separa os dois países. Eles vão à "Escola da Ponte", na parte alta do bairro, e foi lá que assistimos ao curta exibido por mim durante uma aula com recursos de multimídia.

Na escola da Ponte, iniciei a etnografia acompanhando as crianças de uma turma do período da manhã, do sexto ano, com idades de 11 a 13 anos, quando, no meio deles, frequentei esporadicamente as aulas. Fui apresentada como professora da Universidade, às vezes identificada como tal, mas quase todo o tempo era vista como uma adulta a quem podiam contar intrigas relativas aos colegas e a que podia presenciar pequenas ações além das regras de convivência na sala de aula. A diferença de idade entre mim e eles não parecia um grande problema, pois um dia, em uma conversa, disse-lhes que poderia ser avó deles. Igor, um dos alunos, respondeu que ser avó não tinha a "ver nada com a idade", pois a mãe dele era avó, com 40 anos. Ainda nos observávamos quando propusemos, minha orientanda e eu, assistir ao curta-metragem, cuja escolha tematizava o transporte de mercadorias na fronteira. Eu queria a oportunidade de discutir com eles meu interesse de pesquisa, por meio de uma narrativa ficcional, para mim divertida (pela ideia de um bicitáxi, levando e trazendo pessoas com mercadorias entre Paraguai e Brasil), mas também verossímel, pelo cenário. Embora tenha tomado como pressuposto inicial a inexistência de um saber exclusivo das crianças, queria apreender como chegam a saber o que sabem em suas intersubjetividades em contexto (Toren, 1993, 2009).

Apresentar um saber das crianças sobre um modo de vida, do qual são parte, a respeito das atividades de trabalho de adultos, exige a explicitação dos elementos significativos, sociais e antropológicos que, como quero evidenciar, compõem um quadro convencional inter-relacionado: o saber local (das crianças e dos adultos), a escola, o trabalho, a ilegalidade, a fronteira e o Estado-Nação. Explicitá-los é, consequente e simultaneamente, primeiro, expor um contexto particular que as crianças ajudaram a objetivar, de um ângulo próprio; segundo, evidenciar que esse ângulo não é distante do de 
outros adultos aí diferentemente posicionados; e, terceiro, que ter o foco etnográfico em crianças ajudou-nos a ampliar a compreensão dos modos de existências induzidos por uma fronteira.

Para apresentar meu argumento, desenvolvo o artigo em quatro partes, partindo do contexto convencional mais amplo, estratégia que possibilitará, ao final do artigo, entender a profundidade do saber compartilhado pelas crianças. Na primeira, apresento a paradoxal presentificação da fronteira do Estado-Nação brasileiro na experiência rotineira escolar e na experiência de todos os moradores de Foz do Iguaçu, privilegiando a convivência ambígua entre legalidade e ilegalidade, modo pelo qual o Estado-Nação é feito e (des)feito na fronteira pelo movimento clandestino de coisas de um lado da fronteira nacional para outro. Na segunda, exponho a gramática moral peculiar ao contrabando e ao descaminho: desde a dimensão legal da fiscalização e controle, que tentam domesticar essa atividade em nome da defesa da soberania nacional em termos territoriais e econômicos, até a dimensão moral de quem transporta mercadorias, marcada pela ilegibilidade constitutiva do Estado-Nação na fronteira. Na terceira, descrevo a Escola da Ponte inserida nesse contexto e, na quarta, discuto o pressuposto sobre o saber das crianças a partir da conversa com elas sobre o curta-metragem cujo tema é o fluxo de coisas e pessoas na fronteira.

Para circunscrever o argumento proposto, é importante fazer quatro considerações interdependentes. A primeira é que a interrogação sobre modos de vida de pessoas que vivem, por meio do trabalho, a disjunção entre o ilegal e o legítimo, entre o ilícito e o rotineiro, não supõe, a priori e necessariamente, uma defesa desse modo de vida sustentado por atividades ilícitas e menos ainda acatar a obviedade das definições dessas atividades como ilegais. Nas duas situações, a reflexão não sairia dos limites impostos por essas definições e ficaria fechada neles mesmos, sujeitos, por um lado, aos condicionantes trazidos pelo aparato jurídico, legal e estatal, que tenta regular as normas das atividades industriais e comerciais no País e entre os países; e, por outro, às percepções advindas da imagem transmitida pela mídia, veiculada nacionalmente pela cultura pública, da vida nas três fronteiras como arbitrária, sem lei e perigosa. Porém, ao considerar que a ilegalidade pode ser um elemento positivo do funcionamento social (Foucault, 1994) ${ }^{3}$ — pois o dispositivo legislativo tem lacunas por onde a lei

3 'L'illégalisme n'est pas un accident, une imperfection plus ou moins inévitable. C'est un élément absolument positif du fonctionnement social, dont le rôle est prévu dans la stratégie générale de la société. Tout dispositif législatif a ménagé des espaces protégés et profitables où la loi peut être violée, d'autres où elle peut être ignorée, d'autres, enfin, où les infractions sont sanctionnées" (Foucault, 1994, pp. 719-720). 
pode ser ignorada-; no espaço escolar, parecem estar mais visíveis esses hiatos dissonantes entre legalidade e ilegalidade, vividos por adultos e pais dessas crianças, em suas relações com professores e outros agentes nesse contexto. Eles estão incorporados no cotidiano das atividades de transporte de mercadorias, mas condicionados, na escola, por dispositivos legais reguladores da existência civil, dada a obrigatoriedade da educação no País.

A segunda consideração é que as problematizações sobre a escola e suas inter-relações com o contexto social nos remetem a desafios analíticos importantes, sobretudo quando há etnografia com participação e colaboração de crianças, tematizando problemas que não só relativizam, mas também extrapolam a aquisição de conhecimentos em diversos ângulos de experiências das crianças em processos de escolarização (Guerrero, Clemente, Milstein \& Dantas-Whitney, 2017; Milstein, Clemente, Dantas, Guerrero \& Higgins, 2011; Pires-Santos, Lunardelli, Jung \& Silva, 2015; Silva, 2016). Contudo, essa problematização não será feita aqui. Parto assim do pressuposto de que a escola é inseparável do contexto local, porque esse contexto está na escola, perpassado tanto pelas políticas públicas nacionais da educação quanto pelas tensões sociais e políticas vinculadas, direta ou indiretamente, a todos os agentes que dela participam, desde os alunos até os moradores do bairro e da cidade onde se insere.

A terceira consideração é que as injunções da (i)legalidade/legitimidade nos saberes locais não escolares das crianças em uma escola supõem entendê-la não apenas como uma instituição reprodutora legítima das desigualdades e das distinções sociais, ao modo de Bourdieu (1992), ou formas de poder ou de resistência imanentes a essa reprodução (Foucault, 1988, 1999). Inseparável desse contexto singular e ambíguo, é importante também pensar a inserção dos agentes da escola nessa forma de conhecimento coletivo, visto como fenômeno histórico, social e culturalmente situado, tanto em termos políticos (Bourdieu, 1992, 2007; Lahire, 2003), quanto na prática social cotidiana (Lave, 1988, 1991, 1996; Toren, 1993, 2003). Isso requer atenção ao modo como as crianças e os adultos constituem o conhecimento nesse contexto singular, que se supõe saber o que todos sabem, mas não deve ser revelado, e cuja transgressão é relativamente tolerada. Em outros termos, trata-se de pensar a escola e, correlativamente, a educação como uma importante questão política para os grupos sociais implicados em suas práticas. Como sugere Agamben, é, talvez, "a partir destes terrenos incertos e sem nome, destas ásperas zonas de indiferença que deverão ser pensadas as vias e modos de uma nova política" (Agamben, 2002, p. 192).

A quarta consideração é que utilizo, de forma complementar, o conceito de segredo público para adjetivar o que estou denominando como 
saber local comum ou conhecimento coletivo. Proposto em uma das publicações de Taussig, Defacement: Public Secrecy and the Labor of the Negative (1999, p. 5), a quem sigo parcialmente pela instigante inspiração trazida ao tema ${ }^{4}$, o segredo público é definido como "aquilo que é geralmente conhecido, mas, por uma razão ou outra, não pode ser revelado". Como uma forma de conhecimento social, prossegue ele, a instável e a incapturável mistura contida no segredo público é tensionada, ao mesmo tempo, pela dialética entre ocultamento e revelação. Recorrendo a Simmel (1986), Taussig evidencia o segredo público como um divisor entre o exterior visível e uma invisível profundidade interior que, no mesmo movimento, comporta e determina o exterior de um mundo social. O "segredo público" é aquilo que é conhecido socialmente, mas por algum motivo não pode ser articulado, sendo intrínseco ao poder ${ }^{5}$. Esse segredo tem menos importância naquilo que oculta (afinal todo mundo sabe o que não deve saber) que naquilo que afirma: o pertencimento a um contexto jurídico, político e institucional marcado por experiências paradoxais de (i)legalidade na fronteira do Estado-Nação brasileiro revividas na escola.

Uma contribuição relevante para este artigo advém das análises de Christina Toren, que permite compreender o processo constituinte do saber das crianças como intersubjetivo. Ela utiliza o conceito de mente para, e em diálogo com as teorias de aprendizagem, argumentar que o saber é função de todas as pessoas em suas relações intersubjetivas com outras; de que somos produtos dinâmicos da história desse processo, ele mesmo embutido em relações próximas e contínuas com coespecíficos (Toren, 2009). É sob essa perspectiva que evidencio um saber local encontrado na Escola, advindo de intersubjetividades próprias da experiência cotidiana, vivida pelo posicionamento particular do grupo de pessoas com os quais as crianças dessa escola vivem. As crianças e esses grupos estão inseridos em

4 O tema do segredo público no livro de Taussig está relacionado com a força transgressiva da negação, contida no processo de desfiguração (defacement), ato de sacrilégio que, no mesmo movimento, revela o sagrado. Discutindo o tema por meio de obras literárias e de etnografias, ele o expõe nas primeiras linhas do prólogo: "When the human body, a nation's flag, money, or a public statue is defaced, a strange surplus of negative energy is likely to be aroused from within the defaced thing itself. It is now a state of desecration, the closest many of us are going to get to the sacred in this modern world" $(1999$, p. 1).

5 Taussig cita a "lei do silêncio", expressão utilizada pelos colombianos nos anos 1980 para o segredo público em um contexto no qual, ao mesmo tempo em que ocorriam a suspensão emergencial de liberdades civis e a imposição de ordens militares, corpos mutilados apareciam misteriosamente em estradas que conduziam às cidades. As pessoas sabiam que esses massacres aconteciam, "e seus autores 'sabiam' que nós 'sabíamos'", mas não havia uma maneira de articular facilmente os acontecimentos cara a cara e publicamente entre as pessoas (1999, pp. 5-6). 
uma circularidade de alteridades, de forma que o saber local excede e, ao mesmo tempo, é intrínseco ao posicionamento nessa circularidade.

A abordagem de Toren é parte de um debate desenvolvido pela Antropologia da Cognição, que se volta para as crianças ao tentar responder como o conhecimento é aprendido, construído, mantido e reformulado (Ingold, 1991, 1993, 2002; Lave, 1988, 1996; Lave \& Packer, 2011; Toren, 1993, 2003, 2010, 2012) ${ }^{6}$. Esse debate se estabelece nas relações entre a Antropologia e a Educação, de origens longínquas com Boas, Ruth Benedict e Margareth Mead, como mostrou Gusmão (1997).

\section{Contexto escolar de fronteira e atos do Estado7}

A localização da "Escola da Ponte", voltada para o atendimento educacional às crianças residentes na encosta do rio que demarca a fronteira com o Paraguai, a torna inseparável dos modos de vida fronteiriços, com seus vínculos com o Estado-Nação. Um dos exemplos evidenciou-se, pelas formulações da existência de um saber explicitado no início da pesquisa, na voz de uma criança reproduzindo o imperativo de sua avó: "tomar cuidado com o que falo" (Silva \& Godoy, 2016). Naquele momento, juntamente com uma orientanda, queríamos verificar o autoentendimento das crianças sobre as práticas e os saberes compartilhados por elas e relacionados a um modo de vida dos adultos, cujo trabalho de transportar mercadorias atravessando a fronteira é tipificado como ilegal (contrabando e descaminho). O que as crianças viviam, sabiam e falavam eram respostas parciais a um modo de existência por elas presenciado e experimentado, enunciado por reticências na comunicação entre nós, mas paradoxalmente perceptível nos desenhos delas. Esses comunicavam o cotidiano das atividades do bairro, inserido na paisagem reconhecível nas figurações da

6 Há ainda a Antropologia da criança, cuja abordagem tem pressupostos específicos (Cohn, 2000, 2005; Pires, 2010). Desdobramentos dessas abordagens resultam em debates sobre a possibilidade de estudos etnográficos com crianças e/ou com participação e colaboração delas, como mostram Milstein (2009), Guerrero et al. (2017) e podem ser encontrados em Pires-Santos et al. (2015) e Silva (2016).

7 Bourdieu propõe a possibilidade de pensar o Estado por meio de "atos que podemos chamar de atos de 'Estado' —pondo 'Estado' entre aspas—, isto é, atos políticos com pretensões a ter efeitos no mundo social" (2014, p. 46). Tais atos políticos "devem sua eficácia à sua legitimidade e à crença na existência do princípio que os fundamenta" (2014, p. 46). Atos do Estado são, por exemplo, aqueles implementados por todos os agentes encarregados de cobrar, fiscalizar e controlar impostos, como também de todos os agentes do contexto escolar que implementam, em nome do Ministério da Educação e de todas a suas instituições, ações educativas autorizadas e legítimas pela delegação do poder central do Estado. 
Ponte da Amizade sobre o rio Paraná (que liga o Brasil e o Paraguai) dos barcos carregados com mercadorias atravessando o rio e na vegetação às suas margens, das pessoas e dos carros transitando pela ponte e do comércio ambulante nas ruas.

Da experiência etnográfica recente e retomando os dados anteriores, observei que, enquanto as imagens objetivavam a vida cotidiana, as reticências na fala das crianças pareciam expressar menos o que revelavam os desenhos, indicando uma forma de conhecimento velado e um tipo de comunicação que poderiam ser vistos como autoproteção e separação das crianças frente a nós, adultos, e separação entre os que vivem das práticas ilegais daqueles que não o fazem. Para nós, essa forma de conhecimento foi imediatamente reconhecível porque, mesmo não participando diretamente das atividades de transporte ilegal de mercadorias, estamos inseridos no comércio transfronteiriço e local como algo do qual fazemos parte, como moradoras da cidade, presenciando ou sabendo pela divulgação nos jornais locais e também como "bons compradores", com salário regular (como funcionárias públicas) e cartão de crédito. Todos somos, assim, "afetados" (Favret-Saada, traduzida em Siqueira, 1991), direta ou indiretamente, por modos de conhecimento vinculados às práticas do contrabando e de descaminho, como as identificam os agentes da fiscalização e controle; pelo comércio transfronteiriço, como as caracterizam os agentes do turismo local e da administração municipal; e pelo trabalho legítimo, como as descrevem aqueles que delas vivem. Igualmente compartilhamos essa forma de conhecimento, pois "sabemos" quando não se pode falar, o que uma pessoa diz vagamente que trabalha no Paraguai. Repensando essa experiência sob a perspectiva do segredo público, e em virtude da familiaridade do tema, nossas conversas com as crianças, seus desenhos e seus escritos foram incorporados por seus significados autoevidentes, para nós e para elas, de que todos sabíamos e sabemos do que se trata, embora de modo e em posições sociais diferentes.

Menos evidentes e, até mesmo inesperados, foi encontrar, na escola, atos do Estado incorporados pelos agentes e regulamentos da Receita Federal, mediados pelo Programa Nacional de Educação Fiscal (PNEF) (Ministério da Fazenda, 2009). Trata-se de material pedagógico elaborado, no Paraná, para professores, e de duas revistas infantis de histórias em quadrinhos com o objetivo de promover a compreensão da função socioeconômica dos tributos (Dell'Angelo, Souza, Nascentes \& Santos, 2007; Pinto, s. f.). Também encontrei uma "revista educativa" elaborada pelo Fórum Nacional contra a Pirataria e a llegalidade (FNCP) (s. f.), criada pelos representantes da indústria brasileira e da Receita Federal. Nas três revistas, os enredos e a linguagem dos quadrinhos visavam ensinar o que é e o que significa a arrecadação de 
imposto, a sonegação, o cupom fiscal e os gastos do governo, bem como enfatizar a importância da fiscalização e do controle. A "revista educativa", sem identificação de autoria, elaborada sob a coordenação do FNCP, é ambientada em Foz do Iguaçu e narra a história do trabalho de fiscalização de Adu e Ana, personagens e título da revista Aduana. Os dois jovens fiscais, um rapaz e uma moça uniformizados, entram em um ônibus de turistas para verificação de bagagem e, ao encontrarem agrotóxicos ${ }^{8} \operatorname{com}_{\text {um }}$ dos passageiros, encaminha-o para a Polícia Federal. Paralelamente, ao mudar o cenário para uma gruta escondida nas rochas atrás das quedas de águas das Cataratas, onde se veem caixas de brinquedos, óculos, telefone, etc. amontoados, ocorrem cenas de um diálogo entre personagens irritados, sem nomes, cujo líder é caracterizado por trajes estilizados de um pirata. Na contracapa da revista, há a imagem de outro pirata, feio e repugnante, segurando entre as mãos brinquedos, celulares, cds e outros produtos, antecedida da legenda: "Não existe pirata bonzinho!" (Fórum Nacional contra a Pirataria e a llegalidade, s. f.).

Talvez o programa de educação fiscal direcionado às crianças não cause nenhuma surpresa em escolas de outros locais e cidades, mas, sobretudo na escola em questão, se revela como um encontro ao mesmo tempo discrepante e apropriado. Discrepante em razão das atividades juridicamente tipificadas como ilegais exercidas pelos pais e por adultos com quem as crianças da escola vivem. Apropriado, pois é um ato do Estado direcionado às crianças, congruente com a presença das atividades de controle e fiscalização aduaneira da Receita Federal na fronteira, a maior e mais importante no País, recentemente transformada de Delegacia da Receita Federal para Alfândega.

Essa é uma demonstração da paradoxal presentificação, na fronteira, dos atos do Estado-Nação brasileiro na experiência rotineira escolar e exemplifica a experiência de todos os moradores de Foz do Iguaçu, cidade conhecida como destino turístico internacional, e por meio do noticiário nacional, pela divulgação recorrente de apreensão de grande volume de cigarros, drogas, medicamentos e armas contrabandeados. É uma visão comum de estudiosos sobre fronteiras de que os que nela vivem estão imersos em ambiguidades, dadas as oportunidades, os interesses, os recursos e os limites instituídos na própria travessia, tanto pelas diferentes razões que os impele a atravessá-las, como também pelo maior ou menor rigor pelo

8 A região oeste do Paraná, onde se localizam as três fronteiras, se sobressai na utilização de agrotóxicos proibidos no território nacional por estarem relacionados às intoxicações agudas, abortos, malformações, câncer e até a morte, afetando o direito à saúde, como mostram Bastos \& Esquivel (2017). 
qual são controladas ${ }^{9}$. Desse modo, na fronteira, as contingências que tornam problemático o ilícito são igualmente constitutivas daquilo que as cria como ilícito no momento da travessia, como em Foz do Iguaçu, na fronteira entre o Brasil e o Paraguai. O limite entre o dentro e o fora do espaço político do Estado-Nação é marcado pelo controle de fluxo de coisas e pessoas, fazendo dos habitantes fronteiriços um coletivo que se constitui como um "nós" (brasileiros) para outras nacionalidades (paraguaios, argentinos) e no interior da própria nacionalidade (fronteiriços), bem como um "eles" para as autoridades de fiscalização e controle, identificação daqueles que fazem transportes ilegais. O vocábulo "ilícito" expressa aí o que é contrário aos valores sociais ou costumeiros, um significado amplo que difere do ilegal, contrário à lei. No contexto etnográfico, o nebuloso trânsito entre o ilegal e o legal desliza para uma categorial local, a "cultura do ilícito", comum principalmente entre os agentes judiciários.

Afirmar que as fronteiras unem e dividem Estados-Nações e que a existência delas como barreiras ao movimento pode criar simultaneamente razões para as atravessar pareceria uma banalidade, mas é um instigante desafio teórico-metodológico acompanhar as situações empíricas em que elas são instituídas, diluídas e relativizadas, demarcando com mais ou menos rigidez os limites jurídico-políticos entre os diferentes grupos que as atravessam. Por isso, adoto aqui uma orientação geral da Antropologia, pensando fronteira e Estado-Nação, antes de tudo, como categorias sociais próprias de experiências coletivas. Na Nação, como sugeriu Peirano, está subsumido o Estado, forma pela qual identificamos grande parte das sociedades contemporâneas. Categoria como Estado-Nação, apesar de tender à universalização, depende de processos históricos e sociais a serem observados, descritos, analisados e submetidos a reflexões epistemológicas a respeito das condições que os produziram. Sob essa perspectiva, aproveito a sugestão feita por ela: "observar o Estado em ato, a nação se fazendo" (Peirano, 2006, p. 136).

Tendo essa perspectiva como pressuposto, a particularidade da mencionada experiência escolar na fronteira pode ser entendida por meio do conceito de margem do Estado, proposto por Veena Das \& Débora Poole (2008), para pensar a convivência ambígua entre legalidade e ilegalidade, intrínsecas à lei e à sua aplicação, e as formas de produzir cidadãos diferentemente posicionados em relação ao Estado-Nação ${ }^{10}$. O segredo é aí uma

9 Donnan \& Wilsson (1999), Faulhaber (2001), Rabossi (2010), Silva \& Pires-Santos (2011), Macagno, Montenegro \& Béliveau (2011).

10 Em artigo anterior, enfatizamos os atos do Estado que associam noções como sigilo e legalidade, fronteiras e margens problematizados em relação de grupos de pessoas diferentemente posicionados em relação ao Estado (Silva \& Campos, 2018). 
configuração de saberes e práticas a qual tanto exclui quanto inclui pessoas em relação aos atos do Estado. Sob essa perspectiva, a margem não se refere a um espaço social entre periferia e centro das relações de "cidadãos" com as instituições do Estado e seus agentes, mas como "espacios, formas e prácticas a traves de los cuales continuamente el estado es tanto experimentado como deshecho en la ilegibilidad de sus próprias prácticas, docu-

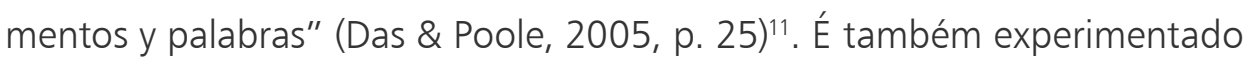
e desfeito na fronteira pelo movimento clandestino de pessoas e coisas de um lado da fronteira nacional para outro.

Pensar nas margens do Estado por meio dos atos e regulamentos é atentar para saberes e práticas em suas injunções com os ilegalismos ${ }^{12}$, que desestabilizam e, simultaneamente, reforçam a dimensão simbólica e política desse poder emergente na escola, ela mesma um signo da presença do Estado-Nação ao promover o ideário da cidadania por meio da educação. No contexto etnográfico, além das políticas e dos programas educacionais de abrangência nacional e dos dispositivos disciplinares escolares, estão os confrontos com atos e regulamentos do monopólio estatal de arrecadação de imposto ${ }^{13}$, mencionados acima.

No espaço físico da escola —onde se encontram crianças, professores, pais, gestores escolares, representantes judiciais e gestores de políticas públicas governamentais - vêm à tona diversas práticas e saberes constitutivos da delimitação geopolítica do Estado-Nação ao mesmo tempo em que se desestabiliza essa delimitação pelos ilegalismos advindos do trabalho. Dessa forma, as crianças, na escola, como espaço social, compartilham um segredo público que, no mesmo movimento, protege e distingui

11 Correlativamente, distante da imagem comum da fronteira como espaço de desordem e sem lei, em Foz do Iguaçu, salta aos olhos a presença excessiva da vigilância fronteiriça, feita pela Polícia Federal, pela Receita Federal, além do exército, marinha e aeronáutica, fazendo dela, talvez, o espaço fronteiriço mais vigiado do País. A argumentação de Weber (1994) sobre o Estado como uma organização política cuja existência e ordem são mantidas pela ameaça da força física é, aqui, inequívoca.

12 Aproveito a expressão "ilegalismo" de Vera da Silva Telles, definido como "um conjunto de atividades de diferenciação, categorização, hierarquização postas em ação por dispositivos que fixam e isolam suas formas e tendem a organizar a transgressão das leis em uma tática geral de sujeições" (2010b, p. 102), mas igualmente de resistência.

13 O monopólio estatal da arrecadação de imposto é explicitado na nação, como um território juridicamente regulado, e na construção do cidadão ligado ao Estado e a outros cidadãos, pelos direitos e deveres (Bourdieu, 2014). Esses elementos estão cristalizados nos regulamentos e nas ações da Receita Federal, primeiro na organização administrativa para arrecadação de imposto e, depois, na presença ostensiva da burocracia estatal na aduana brasileira na fronteira com o Paraguai e a Argentina e no aeroporto da cidade, com ações de fiscalização e proteção aduaneira. 
todos aí implicados. São as condições implícitas nesse segredo público que apresento a seguir, passo importante para compreender a recepção do curta-metragem Bicitáxi.

\section{Do crime sem castigo (?) ao segredo público ${ }^{14}$}

Ter a escola como propiciadora de um espaço de sociabilidades, cuja zona de indeterminação entre o ilegal e o legítimo constrói um espaço de comunicação com pessoas para além das fronteiras do Estado-Nação, e considerar que os dispositivos legislativos têm espaços nos quais a lei pode ser violada ou ignorada, abriu pistas para a pressuposição de que haveria hiatos dissonantes do Estado-Nação presentes na vida de pais, alunos, professores. Os hiatos estão incorporados na opacidade vivida, por um lado, entre o cotidiano das atividades ilegais, mas, por outro, condicionados por dispositivos legais reguladores da existência civil de pais e adultos que trabalham nessas atividades. Por meio dos controles disciplinares atravessados na escola, exige-se deles desde os documentos obrigatórios de matrícula até o controle de frequência das crianças como condição de participação nos programas sociais, a exemplo do Bolsa Família, bem como os atos do estado de educação fiscal mencionados.

Ao focar a atenção na zona de indeterminação entre o legal e o ilegal, minha preocupação centrou-se nas formas diferenciadas de autoentendimentos compostas de transgressões múltiplas, mais ou menos toleradas, de grupos que vivem ou estão implicados direta ou indiretamente nas ações na fronteira e em relações que ligam uns aos outros a despeito de diferentes origens e posições em diálogo por esse contexto. Por isso enfatizei o autoentendimento de diferentes grupos na fronteira como uma espécie de racionalização que justifica rotineiros e persistentes trânsitos entre legalidade e ilegalidade, visíveis nas ações de quem transporta, de quem compra e consome mercadorias de contrabando e descaminho, incluindo aqueles responsáveis pelas ações de fiscalização, controle e repressão do lado brasileiro com a fronteira do Paraguai. Nesse contexto, o autoentendimento das crianças da escola a respeito das atividades de seus pais no transporte de mercadorias é identificado por verbos de ação como "passar", "puxar" e "carregar" mercadorias — significando que os pais delas não vivem na ilegalidade, mas trabalham para os "patrões" que compram essas mercadorias-. Tal entendimento se comunica com a concepção da Justiça, expresso nos regulamentos tipificadores dessas atividades como crimes de

14 Argumentos desta sessão foram antes usados em Silva \& Campos (2018), no artigo "Políticas do segredo: incursões etnográficas no campo da (i)legalidade fiscal", publicado pela revista Ambivalências. 
contrabando e descaminho. Esses autoentendimentos comunicam-se com o dos consumidores, que fazem dos "muambeiros" ou "laranjas" (quem transporta as mercadorias) mediadores para um consumo de mercadorias "justo" e aceitável, mesmo sendo ilegal, pois justificado pela alta taxa tributária no Brasil. Na cultura pública, transmitida por grandes jornais e outras formas de mídias nacionais e locais, as atividades "ilícitas" na fronteira são vistas como descontrole, e a linguagem dela aproxima-se da linguagem jurídica. Para o autoentendimento sociológico local, trata-se de um modo de vida socioeconômico e espacial, dotado de relações de produção reguladas por diferentes sistemas jurídicos, mesmo subordinado ao sistema capitalista global (Abínzano, 2013). O comércio ilícito é visto como atravessado por redes transnacionais, regionais e extrarregionais (Cardin, 2011; PinheiroMachado, 2009). Para quem vive dessas atividades, trata-se de um trabalho legítimo e "informal", porque não é "reconhecido perante a lei, não tem registro. Seria ilegal para o autoentendimento dessas pessoas se elas tivessem 'tirando de alguém', roubando ou revendendo" (Barros, 2008, p. 82).

Um indício da racionalização contida nesses autoentendimentos, oscilando entre a tolerância, a transgressão consentida e a repressão, está na formulação da ideia de um "crime sem castigo", título de um caderno especial do jornal Folha de S. Paulo ("Crime sem castigo: tudo sobre o contrabando no Brasil", 12 de março de 2015). O título é alusivo ao conhecido romance de Dostoiévski, Crime e Castigo, (1982), cujo tema é justamente as ambiguidades entre a moral e as leis. Cometendo um crime, o personagem Raskolnikov escapa impune, mas, torturado pela culpa, acaba "confessando-o" e sendo condenado. A supressão da conjunção "e", atando crime e castigo, substituída pela preposição "sem", desatando a oposição entre os substantivos, manifesta o trânsito nebuloso entre o legítimo e o ilegal, implícito na extensa reportagem multimídia sobre o "universo do contrabando no Brasil". Ao aproveitar o ensejo do Dia Nacional do Combate ao Contrabando ${ }^{15}$, a reportagem pretendeu abranger desde o consumidor até os "impactos do comércio ilícito no Brasil, que movimenta bilhões de reais e se organiza, cada vez mais, como um setor paralelo da economia". O título do Caderno remete à ideia de que

os líderes da quadrilha se escondem em brechas de uma lei que considera a venda ilegal de mercadorias um crime menor, afiançável, com pena de até cinco anos quando os produtos são proibidos (contrabando) e

15 A iniciativa partiu do Instituto Brasileiro de Ética Concorrencial (ETCO), do Fórum Nacional Contra a Pirataria e a llegalidade (FNCP) e mais de 20 instituições empresariais, contando com o apoio do Sindicato Nacional dos Analistas-tributários da Receita Federal (Sindireceita). 
de até quatro quando não legalizados, burlando o fisco (descaminho). Os processos penais contemplam apenas desvios superiores a $\mathrm{R} \$ 20$ mil em impostos ("Crime sem castigo: tudo sobre o contrabando no Brasil", 12 de março de 2015).

Como escrito no jornal, as dificuldades de combate ao contrabando são muitas. Elas se iniciam no interior do aparato de segurança e das instituições judiciárias, com o suborno e as propinas pagas a policiais e a agentes da Receita Federal16. Os próprios servidores dessas instituições, segundo o jornal, "afirmam que a legislação brasileira incentiva o contrabando porque poucos 'atravessadores' acabam punidos. Após um flagrante, dois processos são instaurados: um criminal e um fiscal. Mas, em geral, a única pena é a perda da mercadoria"17. Além do mais, "socialmente, é uma prática considerada mais aceitável: quantos cidadãos comuns não vão ao Paraguai comprar um brinquedinho? questiona um delegado" ("Crime sem castigo: tudo sobre o contrabando no Brasil", 12 de marco de 2015).

Na fronteira do Brasil com o Paraguai, esconder em brechas da lei, burlar o fisco, oferecer suborno e propina a agentes da Receita Federal e a policiais são ações descritas no jornal como habituais e, no caso de burlar o fisco, são vistas como "justas" e aceitáveis. Se tais práticas revelam a opacidade entre o legal e o ilegal e parecem mais aceitáveis em situação de fronteira, elas também ocorrem em outros contextos brasileiros, como vem pesquisando Misse (2009), no Rio de Janeiro, e Vera da Silva Telles (2010a, 2010b), em São Paulo. As abordagens analíticas de Telles (2010a, 2010b) e Misse (2007, 2009), centradas respectivamente nos ilegalismos e na categoria "mercadoria política", sem dúvida, são valiosas contribuições para o entendimento de práticas ilegais aceitáveis e até justificáveis, de modo que a produção das margens do Estado, como propõem Das \& Poole (2008), emerge na regulação da economia, na forma de administração da justiça e no monopólio legítimo da violência em práticas disseminadas em diversos contextos pelo País ${ }^{18}$.

16 No livro de Cardin, uma entrevistada, ao contar que "passava muamba" pela Ponte da Amizade, em 1994, diz: "Tinha um federal que mandava carta para falar quando eu deveria passar. Então ele olhava minha bagagem e não tomava nada, assim eu ganhava meu dinheirinho" (2015, p. 15).

17 É a própria lei que considera o descaminho como um crime mais aceitável; e o contrabando não, em razão das penas mínimas e máximas dos tipos penais.

18 Com um foco mais distanciado e abrangente, na sociedade brasileira, as implicações da produção das margens do Estado foram problematizadas por Damatta $(1979,1991)$ como próprias à sociedades relacionais, com seus códigos de comportamento operando simultânea e complementarmente por ideologias individualistas e holistas da sociedade. 
As margens do Estado têm, contudo, especificidades próprias nas fronteiras territoriais e políticas. Conjugam não o legal e o ilegal, mas o legítimo e o ilegal, atingem igualmente o Estado e os grupos nele envolvidos e, principalmente, sob o ponto de vista do segredo público, não afetam a moral pública, pelo menos em Foz do Iguaçu. Em contexto análogo, Janet Roitman (2006) estudou sociologicamente o contrabando de pequenas armas, cigarros, eletrônicos, produtos de informática, conectadas a mercados regionais e internacionais nas fronteiras internacionais de Chade, centro norte da África. O autoentendimento dos jovens que vivem desse comércio é o de que suas práticas são ilegais, mas lícitas e que, a despeito das taxações das autoridades regulatórias afetarem muitas pessoas, eles contam com a tolerância da polícia. No argumento de Roitman, longe de as práticas constituírem-se como uma "economia moral" emergente nas margens do estado fragilizado, é o contrário que ocorre, pois o Estado participa e mesmo inicia práticas econômicas ilegais. Os jovens de Chade Basin dizem ser suas atividades ilegais e ainda lícitas, porque são simples modos de governo e de acumulação econômica, ou um modo de participar de formas de pensar constituintes de uma economia particular (Roitman, 2006). Roitman denomina essas formas de pensar como "ética da ilegalidade", porque elas se referem a vários códigos dessas práticas relacionados a regulamentos governamentais, tráfico, contrabando e preceitos religiosos. Ela descreve o engajamento com as maneiras pelas quais o poder é exercido e a obtenção de riqueza por meio da violência, bem como o endividamento e a ilegalidade. A ética da ilegalidade problematiza certas experiências vividas e conceitos específicos tais como riqueza, trabaIho, acumulação, economia'19.

O argumento de Roitman de que, nas práticas de contrabando e descaminho, o Estado participa —e mesmo inicia práticas econômicas ilegaisé repleto de consequências para a singularidade dos modos de vida da fronteira ${ }^{20}$. O contrabando e o descaminho são coconstitutivos da fronteira,

19 Mesmo centrada nas implicações mútuas entre os regulamentos do Estado e as atividades econômicas, Roitman evidencia novas formas de pensamento e de ação inscritas no Estado-Nação, como a desobediência fiscal (2004), as transformações do Estado afetadas pelas relações transnacionais, internacionais e locais (1999), a vida e a prática de atores no comércio não regulado, bem como o espaço ambíguo que o trabalho deles ocupa entre as intervenções do Estado e a economia nacional (2008).

20 O argumento de que o contrabando e o descaminho são coconstitutivos aos atos do Estado-Nação na fronteira, ao iniciar e participar de práticas econômicas ilegais (Roitman, 2006), é claro nas relações diplomáticas entre o Brasil e o Paraguai. Desde 1957, há um tratado entre os países de abertura do Porto Paranaguá (PR), como área franca para o comércio externo do Paraguai; logo em seguida se dá a construção da rodovia 277, ligando Assunção ao litoral do Paraná e a 
de modo que a vida de trabalho daqueles que se dedicam às atividades de transportar mercadorias pode ser entendido como uma convivência tensa e contínua entre, por um lado, um tipo de transgressão incorporada e consentida e, por outro, a lei. À justificação moral e à neutralização da culpa de que nos fala Misse, traduzida pela fórmula "todo mundo faz", em Foz do Iguaçu se soma ao "todo mundo sabe". Daí a formulação corriqueira do autoentendimento compartilhado, com diferenças sutis, entre grupos em posições diferentes desse funcionamento para se referir ao trabalho de transporte de mercadorias na fronteira: legítimo e ilegal. Embora haja transgressões múltiplas mais ou menos toleradas, dependendo dos grupos aí posicionados, a posição dos "atravessadores", como são identificados os grupos pelos agentes do controle e da repressão, é a menos tolerada, empurrando-os para um convívio permanentemente tenso em suas relações cotidianas na cidade. Tais práticas perduram pela dimensão pública do segredo, são parte de uma forma estratégica de poder e se presentificam em um conhecimento coletivo do qual todos sabem o que não se deve saber.

Essa é a gramática moral peculiar ao contrabando e ao descaminho: de um lado a dimensão legal da fiscalização e do controle que tenta domesticar essa atividade em nome da defesa da soberania nacional, em termos territoriais e econômicos; de outro, a dimensão moral de quem transporta mercadorias, marcada pela ilegibilidade constitutiva do Estado-Nação na fronteira. É verso e reverso do Estado em ato, fazendo-se no momento mesmo em que é desfeito. Do ponto de vista do autoentendimento das pessoas envolvidas, conforme evidenciei, as atividades de transporte ilegal de mercadorias são vistas como legítimas, porque são um meio de garantir a sobrevivência pelo trabalho. Normalmente o trabalho é contratado depois de estabelecidas as relações de confiança entre quem contrata, frequentemente "patrões" que vivem em outros estados do Brasil, e quem faz o transporte, residentes em Foz do Iguaçu. Às vezes, quem transporta mercadorias o faz diretamente para quem compra, mas ocorrem casos de uma pessoa subcontratar outras, que desconhecem para quem o fazem. Por esse motivo, quem se dedica a essa ocupação é identificado como "passeiro", aquele que "passa" (transporta) um volume de mercadorias combinado previamente com os "chefes" ou "patrões", compradores e responsáveis pelo destino das mercadorias. Os atos que presentificam o Estado-Nação, os diferentes e circulares autoentendimentos, bem como os saberes locais compartilhados como segredo público emergem na escola e

inauguração da Ponte da Amizade, em 1965. A integração entre os dois países criou na fronteira um crescimento exorbitante do comércio de produtos importados saídos do Paraguai, sustentado pelos brasileiros vindos de todo o País. 
entre as crianças que nela encontrei e se tornaram visíveis durante a recepção do curta Bicitáxi, apresentado nas duas partes seguintes.

\section{A escola não é um mundo a parte}

A "Escola da Ponte" está localizada no bairro Jardim Jupira. Os limites do bairro são demarcados pelas "barrancas" da margem direita do rio Paraná, fronteira com Ciudad de Este, tendo à frente a ponte da Amizade e a BR 277, que aí se inicia ligando Foz do Iguaçu e Paraguai ao Porto Paranaguá. À esquerda, o limite do bairro é demarcado pela Av. Tancredo Neves, uma rodovia federal de apenas 6 quilômetros/BR 600, que dá acesso à Hidrelétrica Itaipu, endereço da Escola. Os limites do bairro se fecham por dois condomínios residenciais privados em direção à Usina. Parte do bairro caracteriza-se por áreas de ocupação ao longo do tempo (Zamberlan, 2007), com infraestrutura urbana regular, mas muito precária na parte mais baixa, perto do rio e mais distante da escola. Por isso, é frequentemente identificado por todos na escola como "lá embaixo".

Materializando a identificação do "eles" constitutiva das atividades dos moradores como ilegais, o bairro é descrito pelos habitantes de Foz do Iguaçu como perigoso, associado ao crime e ao contrabando, e é também alvo de ações de criminalização por parte de agentes de diferentes órgãos de segurança responsáveis pelo controle na fronteira e repressão de atividades ilícitas. Quase a totalidade dos alunos da escola reside na parte mais baixa do bairro, próxima à barranca identificada pelas crianças como "pedreira"; nessa escola também estudaram seus pais, como afirmaram vários professores. Por estarem associadas a um lugar do "ilícito", as crianças da escola são descritas em situação de risco permanente, como o de se envolverem no contrabando, no tráfico e com más companhias. No Projeto Político Pedagógico (PPP) (Escola Municipal Ponte da Amizade, 2012), a população é caracteriza como sendo "de nível socioeconômico baixo com predominância de trabalhadores da classe autônoma: pedreiros, mecânicos, diaristas, costureiras, ou de empregados instáveis ('laranjas')"21.

Mais que um espaço físico, a localização social singular da escola permite, àqueles que exercem atividades ilegais, convertê-la, às vezes, em veículo de recomposição das relações por participarem nela como cidadãos da

21 A escola tem 11 salas de aula atendendo no horário matutino e vespertino, 1 Centro Especializado para pessoas com deficiência visual (DV), 2 salas de recursos multifuncionais, 1 sala de classe especial, perfazendo um total de 330 alunos, 20 professores especialistas, 2 cozinheiras e 4 auxiliares de serviços gerais. Possui ainda a Associação de Pais, Mestres e Funcionários (APMF) e conta com biblioteca, cujo acervo inclui livros em Braille. 
comunidade "do Jupira", mesmo de um modo oblíquo e múltiplo. A forma de participação de pais, adultos e crianças "do Jupira" na Escola é propiciada pelo segredo público, presentificado por diversas atualizações de um saber que "sabe o que não deve saber" e, ao incluir transgressões toleradas e incorporadas, embaralham, invertem e revertem os sentidos e direções dos ilegalismos constitutivos nas atividades na fronteira. Essas pistas indicam que, na escola, a experiência vivida entre fronteiras não implica anular a diferença entre a lei e a transgressão da lei, mas conviver de modo tenso com a lei e a transgressão consentida da lei (no sentido de que a lei pode ser violada).

É importante observar que o segredo público não é produto da escola. A escola, como outras instituições da cidade, é um espaço social compartiIhado entre todos e no qual o segredo público é operante. Nela, a distribuição das crianças em horários de funcionamento escolar depende do ritmo da ocupação dos pais e dos adultos, bem como define, de certa maneira, o ritmo das atividades pedagógicas. É também como parte desse segredo público que os pais das crianças e/ou adultos com quem vivem têm apreço, lealdade e respeito pelos professores e pela escola. Os sinais de adesão à escola e o respeito aos professores indicam que ela está longe do "trabalho de má fé" institucional (Bourdieu, 2008)22, pois, inseridos nesse saber coletivo, não ocultam aquilo que torna para eles paradoxal a tarefa de educar: transformar a percepção que crianças, pais e adultos têm das práticas ilíticas com a pretensão de fazer do acesso escolar um caminho para outras posições sociais e promover condições ideais de cidadania ${ }^{23}$. Como comentou uma professora, Edilene, durante uma conversa, a escola não é um mundo à parte, um mundo paralelo. Em contexto de injunções de ilegalismos com as práticas locais, o lugar da escola em relação ao Jupira, na cidade, seria análogo ao papel ideal, mesmo controverso, da Organização das Nações Unidas (ONU), mediando relacionamentos, estabelecendo comprometimentos e lealdades. Ao sustentar, mesmo de forma involuntária e imprevista, a continuidade desse paradoxal modo de existência, a escola contribui para recompor formas de participação social e, no mesmo movimento, afeta a legitimidade do Estado, expressando uma lealdade ambivalente.

22 Bourdieu (2008) menciona as contradições e conflitos associados a uma escolaridade sem outra finalidade que não ela mesma, que acaba por reproduzir a exclusão social em práticas imperceptívies, tanto da parte de quem exerce seus procedimentos quanto das vítimas.

23 Tais ideais, como mostrou Dewey (2010), vem do século XIX, quando a Educação converteu-se em uma função cívica e se identificou com a realização do ideal do estado nacional. O "Estado" substituiu a humanidade, e o cosmopolitismo cedeu o lugar ao nacionalismo. Formar o cidadão, e não o "homem", tornou-se a meta da educação. 
Contudo, o Estado-Nação se (des)fazendo na escola ganha materialidade nos programas nacionais derivados de políticas públicas educacionais, cujo exercício expressa a dominação cotidiana em sua bidimensionalidade apontada por Teixeira \& Souza-Lima (2010): "Nas técnicas de gerenciamento da vida social" e nas "técnicas constitutivas do próprio Estado" (Souza-Lima, 2010, pp. 73-74)24. Mas é também nas escolas onde ocorrem inúmeras mediações que colocam em suspeita esse alcance do Estado, sobretudo em ocasiões específicas, como festas e reuniões de pais. Nesses encontros, professores, pedagogos e funcionários administrativos não só "sabem" como também lidam com uma realidade implicitamente dada. Ainda que as formas de trabalho sejam "criminalizadas", todos os envolvidos na escola parecem não se submeter tão passivamente a essas condições. O segredo público é operante na escola, como parece ser na cidade inteira, e é um meio de proteção obtido pelo paradoxo de fazer-se invisível. A confiança mútua, saber calar, ter discrição, "saber o que não deve saber", buscar as palavras apropriadas, buscar a linguagem adequada são agenciamentos práticos que se contornam ou escapam aos dispositivos de poder implicados nas categorias e nas codificações jurídicas aí envolvidas. Por isso, assistir o curta-metragem com as crianças na escola, cujo tema é o contexto onde elas e eu vivemos, ao invés de uma estratégia que pareceria óbvia por sua referencialidade, foi, por sua própria obviedade, um dos meios de ver o modo pelo qual as crianças interagem, observam, escutam e aprendem a respeito desse contexto no qual participam, inseridas em uma circularidade de alteridades que as excedem.

\section{Assistindo ao curta e conversando sobre ele com as crianças}

Assistimos ao curta-metragem Bicitáxi, vencedor do 1. ${ }^{\circ}$ Fast Forward Filmaking Festival Brazil-Curta Iguassu em $2012^{25}$ em uma sala de aula comumente usada para atividades multimídias. Foi um turno de aulas da rotina escolar cedido pela professora. Além do curta, levamos, orientadas

24 O Estado mantém sua base de poder também no controle estatístico da população estudantil. Esse controle se materializa por meio dos registros de matrícula, programas para impedir evasão escolar, como o ficha de comunicação do aluno ausente (FICA), para combater a evasão escolar e o Bolsa Família, e por meio de inúmeros programas de controle capilares, exercidos pela transversalidade da assistência aos menores e às famílias, como o Estatuto da Criança e do Adolescente (ECA) e a lei Maria da Penha, como observo na escola onde venho realizando a pesquisa.

25 O tema do curta, com duração de três minutos e meio, foi sorteado pela organização do festival e, em 48 horas, as equipes produziram tudo: roteiro, filmagem, edição e montagem. A direção foi de Maurício R. Ferreira, a produção de Michele Dacas, com roteiro desses últimos. O cinegrafista foi Marcos Labanca. 
por ela, uma outra narrativa escrita, do gênero discursivo lenda urbana. A discussão da lenda intitulada $O$ homem do saco tinha como tema crianças desaparecidas, mas também trouxe muitos elementos significativos do saber das crianças sobre a história do bairro e de Itaipu, a usina hidroelétrica, e não será abordada aqui. Descrevo abaixo uma sinopse do curta e simultaneamente a interlocução com as crianças. Dessa interlocução, evidencio o que elas sabem a respeito do cotidiano vivido por aqueles que se dedicam a atividades de transporte de mercadorias pela fronteira (vistas como legítimas, mas ilegais).

$\mathrm{O}$ enredo do curta pode ser resumido por meio de duas cenas. $\mathrm{Na}$ primeira, em uma rua movimentada, um casal jovem está em um carro que acaba de interromper o movimento com uma freada brusca e rápida do motorista. A jovem está saindo de dentro do carro com raiva, medo e descontentamento quando o motorista, em tom ameaçador, a chama: ei!!! A mala... Quando a jovem se volta para pegá-la, o rapaz, retendo uma bolsa vermelha entre as suas mãos e as da jovem, a ameaça com um aviso: seguinte, se a casa cair, sou muito pior que a prisão. Embora o motorista use a expressão "mala", utilizarei aqui a expressão "sacola" ou "bolsa", usadas indistintamente por nós, pois o objeto apresentado na cena é uma bolsa.

Na segunda cena, a mesma jovem está na garupa de uma bicicleta, envolvendo os braços no corpo do jovem ciclista para se segurar. Ele veste uma camiseta amarela a indicar que é um "bicitaxista". A bicicleta se move em direção contrária ao ponto de vista de quem os vê, entre os limites estreitos de um corredor formado, por um lado, pelos muitos veículos que estão no mesmo sentido e, por outro, pelas grades e muros de proteção de uma ponte, sobre um largo rio. A jovem, na garupa da bicicleta em movimento, parece serena, imersa em uma atmosfera de alívio e calma, envolvida pela brisa fresca e por um crepúsculo luminoso que acompanham a travessia quando o ciclista diz: "Parece que tem polícia aqui". Imediatamente a expressão da jovem se transforma. Ela lembra, em um rápido flashbak, do momento em que estava no carro com o motorista que lhe entregou a sacola. Torna-se tensa, puxa para si a sacola vermelha, antes pendurada ao lado do corpo, desce da bicicleta e volta alguns metros. Quase correndo, chega às muradas baixas da ponte. Encosta-se e apoia no parapeito com as duas mãos, inclina o corpo para frente em direção ao rio e o observa por alguns segundos. Então, recua, tira a sacola dos ombros e a arremessa com força para o rio, observando-Ihe a queda até tornar-se um pontinho e desaparecer.

Enquanto o curta era reproduzido em uma tela de televisão, poucas crianças se perguntavam sobre as cenas, outras acharam cômica a ideia do bicitáxi, outras queixaram-se dizendo que o filme estava chato ou 
aborrecido, e a maioria não prestou atenção alguma. Inquietos, mas sem fazer barulho e algazarra, trocavam de cadeiras entre si, sentavam no chão, levantavam-se, conversavam e provocavam uns aos outros tocando-se rapidamente, empurrando-se levemente, rindo, fazendo ironias e brincadeiras. Apesar de o curta durar três minutos e meio, tinham a expectativa de que ele terminasse rápido para verem um youtuber local, como queriam, segundo eles, muito mais interessante. Além da clara recusa ao que lhes propunha, o curta parecia não causar nenhuma surpresa e muito menos curiosidade. Atribuímos essa reação talvez à própria narrativa visual construída com cenas fragmentadas, à apresentação da narrativa por pontos de vista alternados (ora do bicitaxista e ora impessoal), à ausência de ações rápidas ou de um certo suspense, mesmo com a música de fundo, que denotava um ritmo apressado e de excitação.

Quando terminou a seção, Janaína (minha orientanda) e eu, desconsertadas, fizemos algumas perguntas:

—Por que o bicitaxista disse que a "correria era grande"?

Luiza respondeu que era por causa da "movimentação".

—“Movimentação de quê?" -insisti.

Marcus: -Porque eles têm que fazer um monte de coisa. Trabalhar, pegar a bicicleta, passar mercadoria, arrumar o pneu.

Regina: —Que mais? Por que a correria é grande?

Nina: —É que vai rápido e volta.

Perguntamos quem eram as pessoas no carro e responderam:

Carlos: —Eu acho que era um táxi.

Igor: - Não era... Ele falou pra ela: cuidado, senão a casa cai.

Janaína (orientanda): - Ele queria pegar ou entregou a bolsa pra ela?

Igor:-Pegou.

Ana:-Queria entregar, mas ele ficou segurando. 
Janaína: - Por que vocês acham que ele segurou?

Artur: - Porque ele queria dinheiro.

Carlos: - Porque ele queria a mercadoria.

Maria: —Não, eu acho que ele segurou pra falar com a mulher.

Amélia: —Pra ela ter consciência do que ela tava fazendo.

Igor: -Ele falou que a casa caiu por causa da mercadoria e daí ela jogou no rio.

Regina: - A gente tá perguntando antes (da jovem jogar a sacola no rio)... Vocês querem ver de novo?

Igor: - Aham, porque a gente não entendeu nada daquela vez.

Regina: -Então agora vamos prestar atenção no que o moço do carro tava fazendo.

As respostas das crianças às nossas perguntas, depois de exibir o curta a primeira vez, eram indícios da pouca atenção que deram a ele. As crianças rearranjaram a sequência das ações e embaralharam o próprio enredo. Por exemplo: a afirmação "se a casa cair, sou pior que a prisão" foi modulada para "cuidado, se não a casa cai" ou "a casa caiu por causa da...".

Elas introduziram na narrativa elementos que não eram explícitos: supuseram a ação do motorista de entregar e reter ao mesmo tempo a sacola à jovem ao fato de a sacola "conter dinheiro" (Artur) e "conter "mercadoria" (Carlos). Também a interpretaram como um recurso usado pelo motorista para "falar com a mulher" (Amélia) e "ter consciência do que ela tava fazendo" (Maria).

Quase se sobrepondo à discussão, Igor disse que o motorista "falou a casa caiu por causa da mercadoria e daí ela jogou no rio" e narrou outra história, não muito diferente do curta, embora informada por ele. Igor seccionou a sequência narrativa e a reordenou, entrelaçando a cena inicial, em que o motorista entrega a sacola, com a cena final, em que a jovem joga a sacola no rio.

Houve também uma atribuição de significado mais denso para a expressão "correria" que qualifica o trabalho do "bicitaxista" que "vai rápido e volta" (Nina) substituída pela categoria "movimentação", que incluiu 
atividades intensas, agitadas e urgentes, porque "eles têm que fazer um monte de coisa (muitas coisas). Trabalhar, pegar a bicicleta, passar mercadoria, arrumar o pneu..." (Marcus).

Essa primeira "reinvenção" parcial do narrado, no curta, é expressão de como um saber próprio das crianças, emergente de seus relacionamentos interpessoais entre adultos, seus pais, professores e nós. Porém, o que nos permitiu ver essa reinvenção é minha proximidade como investigadora desse contexto convencional mais abrangente, circunscrito por um intenso comércio na fronteira. Essa familiaridade foi um dos motivos pelos quais, mesmo diante do (des)interesse, da reação e a resistência das crianças, o curta foi uma importante estratégia de mediação e comunicação entre nós.

Por que "reinvenção"? Por que os significados identificados pelas crianças à fala do motorista, aos significados objetivados na sacola e à movimentação intensa de atividades não fazem parte do curta.

No curta, o argumento central é o de ir e vir do bicitáxi por uma fronteira, que podemos identificar, sem muito esforço, como a fronteira entre Ciudad del Est, no Paraguai, e Foz do Iguaçu, no Brasil: a Ponte da Amizade, o edifício onde está escrito Receita Federal no Brasil e uma placa de sinalização de trânsito indicando a entrada para o Paraguai. As cenas iniciais focalizam o "bicitaxista" guiando sua bicicleta, em meio a um enxame de mototaxistas, com seus coletes amarelos transportando pessoas. O serviço de mototáxi é muito popular na fronteira, pela capacidade de driblar as longas filas de carros e ônibus que se formam para atravessar a ponte. A incessante circulação de pessoas, caminhando apressadas em meio aos carros, atravessando as ruas, carregando sacolas, atravessando a pé a ponte, também compõem o cenário.

Nesse movimento agitado e frenético de ir e vir, o ciclista do bicitáxi transporta, mas também é observador e participante das ações dos personagens, sobretudo quando estão em risco. Com o ponto de vista onisciente da narrativa visual, também participamos das idas e vindas de mais dois personagens. Um rapaz e uma jovem. Ele entrega a ela uma sacola vermeIha enquanto estão dentro de um carro e diz: "Se a casa cair, sou muito pior que a prisão".

A cena final é a da jovem na garupa do bicitaxista, que a alerta sobre a presença da polícia à frente, parando a bicicleta. Imediatamente a jovem corre até a mureta da ponte e joga a mesma sacola nas águas do rio. $\mathrm{O}$ bicitaxista observa um pouco distante as ações da jovem e, em seguida, vai sozinho com sua bicicleta até a mureta da ponte. Melancólico, parece acompanhar com o olhar o desaparecimento da sacola nas águas. O curta termina com o bicitaxista voltando (ou indo) sozinho, cantando uma canção cuja letra diz haver duas coisas bem distintas, o preço e o valor. 
Frente à modulação dessa narrativa, em que as crianças desencaixaram cenas, rearticulando-as de um modo imprevisto, ou as confundiram, unindo sequências separadas, trazendo elementos inexistentes no curta, como uma possibilidade interpretativa, foi que perguntamos se queriam ver de novo. Igor, quem mais aborrecido estava com o curta, engajou-se no debate, concordando e argumentando: "A gente não entendeu nada daquela vez".

Reproduzimos novamente o curta e, em seguida, antes mesmo de nossas perguntas, Igor falou:

Igor: -Ah entendi, ele fala "Se a casa cair, você que vai pra prisão". A mala (sacola) não é dela.

Maria: —Eu não entendo o que tem dentro dessa mala (sacola).

Marcus: -Maconha.

Maria: -Tem maconha?

Artur: -É mercadoria do homem.

Janaína: -E agora, quem é o moço?

Igor: - Entendi mais ou menos. Ele é o patrão dela, meio patrão, daí eles tavam fazendo plano de traficar aquilo e mandar pra outro lugar e daí o cara já avisou: "Ó, parece que tem polícia aqui", daí ela parou, pegou a mala (sacola) que tinha as coisas e jogou lá no rio.

As suposições sobre o conteúdo da bolsa continuaram sendo feitas pelas crianças. Pedro disse que dinheiro não poderia ser, porque a jovem "não seria burra de jogar dinheiro, que ela ia pegar um pouco"; outros comentaram que era droga, crack, maconha, celular ou computador; outro afirmou que era maconha e "não tinha como a jovem se salvar". Uma menina, voz dissonante das suposições que estavam feitas, disse que não "entendia" o que tinha dentro da sacola. Falando todos ao mesmo tempo, ouvimos um deles perguntar ao colega se "asfalto" é uma droga, e lgor respondeu, rindo, dizendo que ele queria dizer "assalto", remetendo a um outro contexto de penalidade.

Depois desses diálogos tão curtos quanto o curta, não quiseram mais falar. A impressão que tivemos é de que finalizaram uma tarefa sem graça. Mais silenciosos do que qualquer outro momento, ainda perguntamos se 
queriam falar mais alguma coisa sobre o vídeo e disseram: "Coloca o Renato Garcia (o youtuber). O corpo seco 2..." que, infelizmente, não conseguimos acessar por causa das dificuldades de acesso à internet na escola. As crianças reagiram desapontadas. Contudo, o pouco interesse, a ausência de curiosidade e a falta de atenção demonstrados diante das cenas do curta-metragem são reveladores da experiência de trabalho colaborativo com crianças em contextos educativos que nos são próximos.

Após as duas exibições estávamos, assim, diante de duas reinvenções do narrado no curta criadas pelas crianças. Na primeira, as suposições das crianças era de que o carro onde estava a jovem era um táxi, que a mala dada a ela pelo rapaz continha "mercadoria" ou "dinheiro" e que a "correria" do bicitaxista era "movimentação". Na segunda reinvenção, a "mercadoria" da mala ganhou formas mais precisas, incluindo objetos de dois subconjuntos com significados do mesmo universo semântico. Um é o das drogas ilícitas, como crack, maconha, pedra e, o outro, de aparelhos eletrônicos, como celular, computador, etc. O rapaz que entregou a mala à jovem foi identificado como um "patrão", "meio patrão", e os dois "tavam fazendo plano de traficar aquilo e mandar pra outro lugar" (Igor).

O que o pouco interesse e, ao mesmo tempo, o modo pelo qual as crianças reagiram às cenas do curta nos dizem? Por que a modulação entre a primeira e a segunda reinvenção não foi discrepante? Por que a reação e a "reinvenção" das cenas por parte das crianças me surpreenderam?

Para começar a responder a essas perguntas, relembro o contexto convencional, reconhecível e familiar no qual todos estamos inseridos, descrito nas páginas iniciais deste artigo, e que permitiu que as crianças pudessem "reinventar", por duas vezes e de modo bem próximo, a narrativa do curta.

O que aprendemos, assistindo ao curta e sobre ele conversando, é que as reinvenções da narrativa do curta pelas crianças revelam um saber comum aos adultos, propiciado pela intensidade de convívio e da proximidade de seu relacionamento com eles no bairro onde vivem. Esse saber é resultante da sobreposição de dois contextos: um contexto convencional dominante, jurídica e politicamente, em que o "trabalho" de transportar mercadorias, exercido pelos pais e adultos com quem elas vivem é ilegal e clandestino; e um contexto reconhecível e crível do cotidiano da vida desses adultos, em que esse "trabalho" é visto como "legítimo". Nessa sobreposição, reagem ao contexto dominante no qual são tanto antítese como síntese: concebem esse trabalho como sendo feito para os outros, "os patrões", e o identificam como "passeiros" (que passam mercadorias). "Passar" é um verbo transitivo, indicando, simultaneamente, passar de um lugar para outro e transpor limites, territoriais, jurídicos e significativos. 
Dessa indexicalidade existente, a comunicação entre nós excedeu a narrativa referencial justamente por causa da participação de todos, deles e nossa, em contexto. Uma vez que os temas e as ideias da narrativa fílmica eram reconhecíveis, a transformação deles na conversa corporificou uma simbolização incisiva, objetivada na sacola, que explicita a dinâmica da interação das crianças entre adultos no contexto do trabalho ilegal, mas vivido e experimentado como legítimo.

A sacola, para as crianças, continha "dinheiro" ou "mercadoria". Categorias comuns no contexto convencional da economia, do comércio, da regulamentação estatal, sob a forma jurídica e fiscal na fronteira, a "mercadoria" é uma categoria social que, para as crianças, é objetivada como diferentes tipos de drogas e como produtos eletrônicos. Identifica tanto o transporte de "mercadorias proibidas" quanto a quantidade e o valor de mercadorias que excedem a cota permitida pela regulamentação aduaneira. A sacola também indica, como um índice, a mediação entre o "patrão" e aquele que transporta a mercadoria. Quando Igor diz "meio patrão", ele quer dizer que o patrão não é um chefe de uma empresa comercial ou industrial e muito menos um proprietário de algum negócio que contrata empregados. O "patrão" é aquele que compra, mas não transporta as mercadorias, é aquele que, ao combinar o trabalho de "passar" as mercadorias, não se sabe ou se omite o nome. "Meio patrão" é como se fosse um patrão, mas não é o patrão. Finalmente, a sacola, como uma fixação dos significados aí interconectados, não é apenas uma descrição explícita. Ela objetiva tanto a mediação entre "patrão" e "passeiro" quanto a sobreposição dos contextos convencionais (jurídico e familiar) articulados ao transporte ilegal, mas legítimo, de mercadorias. Ao afirmar que a jovem, quando soube da polícia, jogou a sacola no rio "porque era maconha e ela ia ser presa. Não tinha como ela se salvar", Igor parece ter entendido a advertência de que, se "a casa caísse, seria pior que a prisão". "Cair a casa" é ser pego pela polícia ou por agentes da aduana brasileira que fiscalizam a entrada de mercadorias na fronteira, mas também pode significar perder os meios de sustentar a própria existência. Também não duvidaram de que a sacola não era da moça. "Não é dela", continha "mercadoria do homem", embora não soubessem ao certo o que tinha dentro.

Ao conversar sobre o curta com as crianças vimos que evocaram um quadro convencional de categorias interconectadas em que as relações delas com os outros dos outros (agentes encarregados do controle e da fiscalização do Estado na fronteira, consumidores, "passeiros") foi objetivado. A sacola igualmente é um símbolo que condensa esse contexto de modos de existência vividos nos hiatos entre o ilegal e o legítimo pelas atividades de 
transporte de mercadorias na fronteira constitutivos do Estado-Nação, dos quais as crianças não estão alheias.

\section{Considerações finais}

No encontro com as crianças na escola, depreendi que elas participam dos elos de encaixe e desencaixe entre diferentes contextos convencionais (do cotidiano vivido pelas crianças entre pais e outros adultos, dos agentes e operadores jurídicos e políticos que regulam, fiscalizam e controlam atos do Estado-Nação na fronteira e dos moradores da cidade). Nessas relações, as crianças produzem significados a partir de outros significados por outros construídos e em construção, sendo transformados, como vimos, no próprio processo em que estão sendo constituídos (Toren, 2009). As crianças se comportam por ações desencadeadas pelas relações com os pais e os adultos próximos, de modo que sofrem constrangimentos e coerções. Igualmente "sabem", reflexiva e instersubjetivamente, por participarem do modo de existência cotidiano vivido entre eles, razão pela qual expuseram esse saber por meio das (re)invenções da narrativa do curta metragem, ainda assim circunscritas a dois contextos sobrepostos: o convencional, que regula as atividades na fronteira, e o reconhecível do cotidiano em que essas atividades são ilegais, mas vistas como legítimas.

Em relação à pesquisa com participação das crianças de contextos próximos, pode-se considerar que a excessiva familiaridade não significa necessariamente que sabemos o que pensamos saber ou compreender. Um elemento importante para refletir foi a assimetria entre os meus interesses e os interesses das crianças, dada pela disjunção entre minha pressuposição da existência do contrabando como algo distante das crianças, na escolha do tema do curta versus a pouca relevância que as crianças deram a ele ${ }^{26}$. Aí reside meu espanto pelo pouco interesse das crianças no curta. Certamente as narrativas do youtuber poderiam revelar outros modos de inserção, além dos específicos de um modo de vida orientando para o trabalho na fronteira. Talvez seja essa a razão pela qual o realismo da produção do curta não foi questionado como ficção, mas interpretado em seu valor referencial. Por isto contrastaram o youtuber (com vídeos de suspense "brincando" com a confusão entre a ficção e a realidade), com o curta, visto

26 Como sugeriu um dos pareceristas, a relação e as atividades com as crianças mereceriam reflexões metodológicas detalhadas da assimetria estabelecida e dos limites e possibilidades trazidos por meios de realização de etnografia em contextos em que "saber o que não se deve saber" são agenciamentos práticos para contornar dispositivos de poder. 
como um "retrato" da realidade próxima, ao contrário da lenda urbana, entendida por um deles como "meio fake e meio verdadeira".

Com a participação das crianças na pesquisa etnográfica, nossa própria familiaridade foi sendo aos poucos transformada em um processo de aprendizagem sobre elas e revelou que elas compartilham um saber a respeito dos riscos do "trabalho ilegal, mas legítimo" dos adultos com quem vivem, incorporado nas relações tensas com o "patrão", no medo de ser pego pela "polícia" e de "perder" as mercadorias, consequência do atos do Estado-Nação em seu controle e fiscalização na fronteira. Esse saber, local e público, portanto, é o mesmo dos adultos (não somente seus pais e adultos com quem vivem, mas professores, gestores e moradores do bairro e da cidade, como eu) e que pode ser formulado como "um saber que todos sabem o que não devem saber". Portanto, não há um saber distinto das crianças em relação ao saber dos adultos com os quais se relacionam. O que há é um saber comum e local que, para elas, implica um cerceamento ao cotidiano vivido. Como crianças, devem "tomar cuidado com o que falam" fora de seu contexto próximo e, talvez, infelizmente, quanto mais "sabem" desse saber, mais enredados nele podem permanecer.

\section{Reconhecimento}

Além do apoio do Conselho Nacional de Desenvolvimento Científico e Tecnológico (CNPq), agradeço à Diretora, professores e crianças da Escola onde venho desenvolvendo a pesquisa etnográfica. Agradeço aos colegas das universidades às quais estou vinculada; minha orientanda à época, Janaina de Jesus Lopes Santana, como também aos Pesquisadores/Coordenadores da Rienn (Red Internacional de Etnografía con Niños, Niñas, Adolescentes y Jóvenes) pela interlocução.

\section{Sobre os autores}

Regina Coeli Machado e Silva é doutora em Antropologia Social, Museu Nacional (UFRJ), Brasil. Professora e pesquisadora Sênior Unioeste, Brasil. Professora e pesquisadora visitante Unila, Brasil. Pesquisadora Produtividade em Pesquisa, Conselho Nacional de Desenvolvimento Científico e Tecnológico (CNPq), Brasil.

\section{Referências}

Abínzano, R. C. (2013). Estudos antropológicos en y de la región de fronteras: cuestiones de teoria e metodologia. Ideação, 15(2).

Agamben, G. (2002). Homo sacer: o poder soberano e a vida nua I. Belo Horizonte: UFMG. 
Barros, A. S. (2008). A informalidade dos laranjas na fronteira Brasil/Paraguai. História na Fronteira, 1(1), 61-88. https://www.google.com/url?sa=t\&rct $=j \& q=\& e s r c=s \&$ source $=$ web\&cd $=\& v e d=2$ ahUKEwjk1JGtk8_pAhWOTN 8KHVfeDPwQFjAAegQIBhAB\&url=https\%3A\%2F\%2Fpleiade.uniamerica. br\%2Findex.php\%2Fhistorianafronteira\%2Farticle\%2Fview\%2F72\%2F62\& usg =AOvVaw3bA301sQuZ29RcxQV7ISXM

Bastos, G. N. \& Esquivel, C. L. W. (2017). O contrabando de agrotóxicos e a violação do direito fundamental a saúde: estudo de caso na região oeste do Paraná. Ciências Sociais Aplicadas em Revista, 17(33), 170-191. http://erevista.unioeste.br/index.php/csaemrevista/article/view/18637/12298

Bourdieu, P. (1992). A reprodução. Rio de Janeiro: Francisco Alves.

Bourdieu, P. (2007). Escritos da Educação. Petrópolis, RJ: Vozes.

Bourdieu, P. (2008). A miséria do mundo. Petrópolis/RJ: Vozes.

Bourdieu, P. (2014). Sobre o Estado. Cursos no College de France (1989-92). São Paulo: Companhia da Letras.

Cardin, E. G. (2011). Laranjas e sacoleiros na tríplice fronteira: um estudo da precarização do trabalho no capitalismo contemporâneo. Cascavel: Edunioeste.

Cardin, E. G. (2015). A expansão do capital e as dinâmicas das fronteiras. Jundiaí (SP): Paco.

Cohn, C. (2000). Crescendo como um Xikrin: uma análise da infância e do desenvolvimento infantil entre os Kayapó-Xikrin do Bacajá. Revista de Antropologia, 43(2): 195-222. http://dx.doi.org/10.1590/\$0034-77012000000200009

Cohn, C. (2005). Antropologia da Criança. Rio de Janeiro: Jorge Zahar.

Crime sem castigo: tudo sobre o contrabando no Brasil. (12 de março de 2015). Folha de São Paulo. http://arte.folha.uol.com.br/mercado/2015/03/12/crimesem-castigo/

Damatta, R. (1979). Carnavais, malandros e heróis. Rio de Janeiro: Zahar.

Damatta, R. (1991). A casa \& a rua. Rio de Janeiro: Guanabara Koogan.

Das, V. \& Poole, D. (2008). El Estado y sus márgenes: etnografias comparadas. Cuadernos de Antropología Social, 27, 19-52. https://www.redalyc.org/ pdf/1809/180913917002.pdf

Dell'Angelo, C., Souza, M. H., Nascentes, N. C. O. \& Santos, R. F. (2007). De olho na cidade. Programa de Educação Fiscal do Paraná.

Dewey, J. (2010). A concepção democrática de educação. Em R. Westbrook et al. (org.)., John Dewey. Recife: Fundação o Joaquim Nabuco, Massangan.

Donnan, H. \& Wilson, T. M. (1999). Frontiers of Identity, Nation and State. New York: Oxford.

Escola Municipal Ponte da Amizade. (2012). Projeto Político Pedagógico. Foz do Iguaçu.

Faulhaber, P. (2001). A fronteira na Antropologia Social: as diferentes faces de um problema. BIB, 51. http://www.anpocs.com/index.php/edicoes-anteriores/ bib-51/522-a-fronteira-na-antropologia-social-as-diferentes-faces-de-umproblema/file

Foucault, M. (1994). Dits et écrits. Paris: Gallimar.

Foucault, M. (1988). Microfísica do poder. Rio de Janeiro: GRAAL.

Foucault, M. (1999). Vigiar e punir: nascimento da prisão. Rio de Janeiro: Vozes.

Forum Nacional contra Pirataria e a llegalidade (FNCP). (s. f.). Adu e Ana: encarando a pirataria e o contrabando. Revista Educativa, 1. 
Guerrero, A. L., Clemente, A., Milstein, D. \& Dantas-Whitney, M. (2017). Bordes, límites y fronteras: encuentros etnográficos con niños, niñas y adolescentes. Bogotá: Editorial Pontificia Universidad Javeriana.

Gusmão, N. M. M. de (1997). Antropologia e educação: origens de um diálogo. Cadernos Cedes, 18(43), 8-25, https://doi.org/10.1590/S0101-32621997000 200002

Ingold, T. (1991). Become persons: Consciousness and sociality. Human Evolution, Cultural Dynamics, 4(3), 355-378. https://doi.org/10.1177/092137409 100400307

Ingold, T. (1993). Technology, language, intelligence: A reconsideration of basic con- cepts. Em K. R. Gibson \& T. Ingold (Orgs.), Tools, Language and Cognition in Human Evolution (pp. 449-472). Cambridge: Cambridge University Press.

Ingold, T. (2002). Culture, perception and cognition. Em The Perception of the Environment: Essays on Livehood, Dwelling and Skill (pp. 157-171). Londres: Routledge.

Lahire, B. (2003). Crenças coletivas e desigualdades culturais. Educação e Sociedade. Campinas, 24(84), 983-995. https://www.scielo.br/pdf/es/v24n84/ a12v2484.pdf

Lave, J. (1988). Everyday Life. Cambridge: Cambridge University Press.

Lave, J. (1991). Situating learning in communities of practice. Em L. B. Resnick, J. M. Levine \& S. D. Teasley (Eds.), Perspectives on Socially Shared Cognition (pp. 63-82). American Psychological Association. https://doi. org/10.1037/10096-003

Lave, J. (1996). Teaching, as learning, in practice. Em Mind, Culture and Activity 3, 149-164.

Lave, J. \& Packer, M. (2011). Hacia una ontología social del aprendizaje. Revista de Estudios Sociales, 40, 12-22. doi: 10.7440/res40.2011.0

Macagno, L., Montenegro, S. \& Béliveau, V. G. (2011). A tríplice fronteira: espaços nacionais e dinâmicas locais. Curitiba: UFPR.

Milstein, D. (2009). La nación en la escuela: viejas y nuevas tensiones políticas en las escuelas. Buenos Aires: IDES/Inst. de Desarrrolo Económico y Social/ Miño y D'Avila.

Milstein, D., Clemente, A., Dantas, M., Guerrero, A. \& Higgins, M. (Eds.). (2011). Encuentros etnográficoscom niñ@s y adolescentes: entre tiempos y espacios compartidos. Buenos Aires: Miño y Dávila, IDES/CAS.

Ministério da Fazenda. (2009). Programa Nacional de Educação Fiscal (PNEF) (4 vols.). Brasília: ESAF.

Misse, M. (2007). Mercados ilegais, redes de proteção e organização local do crime no Rio de Janeiro. Estudos Avançados, 21(61), 139-157. doi: 10.1590/ S0103-40142007000300010

Misse, M. (2009). Trocas ilícitas e mercadorias políticas, para uma interpretação de trocas ilícitas e moralmente reprováveis cuja abrangência no Brasil nos causam incômodos também teóricos. Anuário Antropológico, 35(2), 89-107. https://dialnet.unirioja.es/servlet/articulo?codigo $=7449611$

Peirano, M. (2006). A teoria vivida e outros ensaios de antropologia. Rio de Janeiro: Jorge Zahar. 
Pinheiro-Machado, R. (2009). Made in china: produção e circulação de mercadorias no circuito China-Paraguai-Brasil (tese de pós-graduação). Universidade Federal do Rio Grande do Sul, Porto Alegre, Brasil.

Pinto, Z. A. (s. f.). Que nem gente grande. Programa de Educação Fiscal do Paraná.

Pires, F. (2010). O que as crianças podem fazer pela antropologia? Horizontes Antropológicos, 16(34), 137-157. doi: 10.1590/S0104-71832010000200007

Pires-Santos, M. E., Lunardelli, M., Jung, N. \& Silva, R. C. M. (2015). Vendo o que não se enxergava: condições epistemológicas para construção de conhecimento coletivo e reflexivo da língua(gem) em contexto escolar. DELTA: Documentação e Estudos em Linguística Teórica e Aplicada, São Paulo, 31(número special), 35-65. http://www.scielo.br/scielo.php?script=sci_ arttext\&pid=S0102-44502015000300004\&lng=pt\&nrm=iso. Acesso em 03/07/2016

Rabossi, F. (2010). Como pensamos la Triple Frontera? Em V. Giménez-Béliveau \& S. Montenegro (Orgs.), La triple frontera: dinámicas culturales y procesos transnacionales (pp. 21-45). Buenos Aires: Espacio Cultural.

Roitman, J. (1999). Le Pouvoir n'est pas souverain: Nouvelles autorites regulatrices et transformations des Etats dans le Bassin du Lac Tchad. Em La privatisation des Etats (pp. 163-196). Paris: Karthala.

Roitman, J. (2004). Les recompositions du bassin du lac Tchad. Politique Africaine, 94(2), 7-22. doi:10.3917/polaf.094.0007.

Roitman, J. (2006). The ethics of illegality in the Chad Basin. Em J. Comaroff \& J. Comaroff (Dirs.), Law and Disorder in the Postcolony. Chicago: University of Chicago Press. http://www.decolonizing.ps/site/wp-content/ uploads/2010/03/comaroff-j-and-j-law-and-disorder-in-the-postcolony.pdf

Roitman, J. (2008). A successful life in the illegal realm: Smugglers and road bandits in the Chad Basin. Em P. Geschiere, B. Meyer \& P. Pels (Eds.), Readings on Modernity in Africa (pp. 214-220). Indiana: Indiana University Press.

Silva, R. C. M. (2016). Do Ipê Roxo na Cidade Nova: experiência etnográfica e aprendizagem situada. Etnográfica, 20(1), 119-142. https://doi.org/10.4000/ etnografica. 4225

Silva, R. C. M. \& Campos, M. J. (2018). Políticas do segredo: incursões etnográficas no campo da (i)legalidade fiscal. Ambivalências, 6(12). https://doi. org/10.21665/2318-3888.v6n12p19-46

Silva, R. C. M. \& Godoy, M. E. C. (2016). Tomar cuidado com o que falo: ser criança na escola, ficar e brincar em casa. Revista Latitude, 10(2), 287-319. https://www.google.com/url?sa =t\&rct=j\&q=\&esrc=s\&source=web\&cd $=\& v e d=2$ ahUKEwjm9lj9i8_pAhXHTd8KHdNtCLOQFjAAegQIBBAB\&url $=\mathrm{h}$ ttp\%3A\%2F\%2Fwww.seer.ufal.br\%2Findex.php\%2Flatitude\%2Farticle\%2 Fdownload\%2F2512\%2F3431\&usg=AOvVaw0p-h_3-B0kQDQ8v9wkzSR4

Silva, R. C. M. \& Pires-Santos, M. E. (2011). Cenários em perspectiva: diversidade na tríplice fronteira. Cascavel: Edunioeste.

Simmel, G. (1986). El secreto y la sociedad secreta. Em Sociologia 1. Estudios sobre las formas de socialización (pp. 64-600). Madrid: Alianza.

Siqueira, P. (2005). Ser afetado. Cadernos de Campo, 13(13), 155-161, https:// www.revistas.usp.br/cadernosdecampo/article/view/50263/54376 
Taussig, M. (1999). Defacement: Public Secrecy and the Labor of the Negative. Stanford: Stanford University Press.

Teixeira, C. C. \& Souza Lima, A. C. de. (2010). A antropologia da administração e da governança no Brasil: área temática ou ponto de dispersão? Em C. B. Martins \& L. F. Dias-Duarte, Horizontes das Ciências Sociais no Brasil: antropologia. São Paulo: Anpocs.

Telles, V. da S. (2010a). As cidades nas fronteiras do legal e ilegal. Belo Horizonte: Argumentum.

Telles, V. da S. (2010b). Nas dobras do legal e ilegal: ilegalismos e jogos de poder nas tramas da cidade. Dilemas: Revista de Estudos de Conflito e Controle Social, 2(5-6), 97-126.

Toren, C. (1993). Making history: The significance of childhood cognition for a comparative anthropology of mind. Man, 28(3), 461-78.

Toren, C. (2003). Becoming a Christian in Fiji. An Ethnographic Study of Ontogeny. The Journal of the Royal Anthropological Institute, 9(4), 709-727. doi: 10.1111/j.1467-9655.2003.00170.x

Toren, C. (2009). Intersubjectivity as Epistemology. Social Analysis, 53(2), 130 146. https://www.academia.edu/913697/Intersubjectivity_as_epistemolo gy._Social_Analysis_53_2_130-146._2009

Toren, C. (2010). A matéria da imaginação: o que podemos aprender com as idéias das crianças fijianas sobre suas vidas como adultos. Horizontes Antropológicos, 16(34), 19-48. https://doi.org/10.1590/\$0104-71832010000 200002

Toren, C. (2012). Antropologia e psicologia. Revista Brasileira de Ciências Sociais, 27(80), 21-36. https://www.scielo.br/pdf/rbcsoc/v27n80/v27n80a02.pdf

Weber, M. (1994). Economia e sociedade (vol. 1). Brasília: Editora da UnB.

Zamberlan, J. (2007). Foz do Iguaçu em contexto de mobilidade. Porto Alegre: Solidus. 